\title{
The Challenges of Implementing Prohibition of Torture in Two Levels: ASEAN and Indonesia
}

\author{
Erna Dyah Kusumawati
}

\begin{abstract}
ABSTRAK
Artikel ini menganalisis implementasi larangan penyiksaan level ASEAN dan Indonesia. Pembahasan diawali perkembangan pengaturan dan ratifikasi Konvensi PBB di tingkat ASEAN. Kemudian perkembangan dalam hukum nasional Indonesia. Selanjutnya analisis ditujukan kepada tantangan dan hambatan yang mungkin dihadapi dalam mengimplementasikan larangan penyiksaan di kedua level, regional dan nasional. Hasil analisis menyatakan bahwa larangan penyiksaan termasuk sebagai hak asasi yang bersifat fundamental dan tidak dapat dicabut (non-derogable). Norma larangan penyiksaan juga termasuk sebagai ius cogen atau peremptory norm atau norma yang memaksa dan sudah dianggap sebagai hukum kebiasaan internasional. Dengan demikian, meratifikasi atau tidak negara-negara anggota ASEAN dianggap terikat dan harus memenuhi kewajiban diatur dalam Konvensi Anti Penyiksaan. Terdapat kelemahan dalam tingkat ASEAN, yaitu dalam hal monitoring pemenuhan kewajiban-kewajiban Negara anggota. Badan HAM ASEAN tidak didesain sebagai pengawas yang independen, karena berada di bawah organisasi ASEAN. Pada level Indonesia, penyiksaan masih banyak ditemukan terutama untuk mendapatkan pengakuan tersangka dalam proses penyidikan dan penyiksaan dalam tahanan. Hukum di Indonesia belum berlaku maksimal. Konstitusi dan Hukum Hak Asasi Nasional sudah mengatur bahwa hak terbebas penyiksaan merupakan hak yang tidak dapat dicabut, namun demikian perlindungannya belum maksimal, mengingat KUHP tidak menjamin keseragaman pelaksanaan hukuman bagi pelaku penyiksaan. Demikian juga Pengadilan Hak Asasi Manusia tidak mempunyai kewenangan memeriksa perkara penyiksaan. Sehingga masih banyak diperlukan koreksi dalam hukum nasional, termasuk wewenang investigasi KOMNAS HAM dalam hal terjadi penyiksaan.
\end{abstract}

Kata Kunci : Implementasi, Anti Penyiksaan, Hak Asasi Manusia

\section{ABSTRACT}

This article will address the issue regarding prohibition of torture and its challenges at two levels: ASEAN and Indonesia. The prohibition of torture is considered to be a rule of "jus cogens" or peremptory norm as well as customary law. In addition the prohibition of torture is absolute and nonderogable. Therefore, it entails some obligations for states whether or not they ratify the CAT. States have the universal obligations to prevent torture and inhuman degrading treatment in their jurisdiction under international customary law. Since many of ASEAN countries do not ratified ICCPR, the AICHR have to implement the prohibition of torture based on the customary international law. In addition, AICHR needs to monitor the national law regarding the prohibition of torture. However, the AICHR lacks of protection mandate and might not functioning well especially when dealing with the allegation of the prohibition of torture or other human rights' allegations within ASEAN jurisdiction. In Indonesia, the use of torture to get the confession is widely used by the police. Not all the perpetrators are brought to the Court of Law and are given an equitable sentences; although, Indonesia does have a regulation on prohibition of torture; the Criminal Code, the Law No 39/1999 concerning Human Rights, and the Law No. 26/2000 concerning Human Rights Courts. There is lack of competence of the Indonesian Human Rights Court to hear the violation cases. Also, there is lack of competence of the Indonesian Commission on Human Rights to investigate cases concerning torture.

Keywords: Implementation, Prohibition of Torture, Human Rights 


\section{Introduction}

The development of human rights regime in South East Asia is proceeding more slowly than the development of human rights in their far more modest European counterparts. For example European countries already have their own judicial body to hear the violation of human rights cases; European Court of Human Rights (ECtHR). While ASEAN has the ASEAN Intergovernmental Commission on Human Rights (AICHR); an intergovernmental body which does not have competences to hear the human rights violation cases. Regarding the ratification of international human rights instruments, no ASEAN country has ratified all the 26 United Nations' instruments on Human Rights (Maznah Mohammad; 2002:230-252)

Meanwhile, regarding the Prohibition of Torture, only three countries have ratified the Convention against Torture: Cambodia, Indonesia and the Philippines. (Maznah Mohammad; 2002:230-252) This article will address the issue regarding prohibition of torture and its challenges at two levels: ASEAN and Indonesia. At ASEAN levels, the lack of regional instruments concerning torture and not all member states ratify the UN Convention against Torture (CAT) and International Covenant on Civil and Political Rights (ICCPR) constitute a specific difficulty in preventing torture and inhuman degrading treatment. First, I will describe the development of prohibition of torture at each level; second, I will examine the challenges of implementing the prohibition of torture both at ASEAN level and Indonesia level.

\section{Prohibition of Torture at the ASEAN Level}

I would say that signing the ASEAN Charter as a legally binding agreement of all ten members is a prestigious achievement for ASEAN, after being an association without having a constitution for a long time. It entered into force on 15 December 2008 and it provides legal status and framework for ASEAN. (Charter of Association of South East Asian Nations, Jakarta, 2008) One of the purposes of this Charter is to promote and protect human rights and fundamental freedoms. (Article 1, paragraph 7) This purpose also becomes one of ASEAN principles as it is stipulated in Article 2 paragraph 2 (i). One of the Charter's mandates is to establish the ASEAN Human Rights Body which is responsible for promoting and protecting human rights within ASEAN jurisdiction (Article 14 paragraph 1). However, there are no specific regulations about human rights in the Charter.

Human rights are merely a principle affirmed by all the member states. The specific human rights declaration is the next step which should be concluded by consensus from all member states. However, there is no human rights declaration until present. It means that there is no regional human rights norms served as a legal basis for individuals to file a complaint against their government for human rights breaches at regional level. Thus, the protection of human rights is depended on each member state. If a member state did not willing to protect human rights of its people, then the victims have nowhere to go. The next paragraph will discuss ASEAN Human Rights Body as the idea of the ASEAN Charter.

The ASEAN Human rights body is called the ASEAN Intergovernmental Commission on Human Rights (AICHR). (Term of References-TOR of ASEAN Intergovernmental Commission for Human Rights, Jakarta, 2009) It was adopted on 20 July 2009. The status of the AICHR is a body which will work inside ASEAN, like the Charter's direct mandate. That is to say, the AICHR is never intended to be an independent human rights "watch dog" in ASEAN jurisdiction. (Mr. Termsak Chalermpalanupap; 1, http://www.asean.org/HLP-OtherDoc-1.pdf) In the TOR of the AICHR, there is no regulation about specific human rights and how this body will work to protect human rights for ASEAN people. The idea was only to promote and protect human rights of all people in ASEAN (Article 1, 2, 3). One of the functions of AICHR is also to promote capacity building for the effective implementation of international human rights treaty obligations undertaken by ASEAN Member States. This job will probably be difficult, since not all member states of 
ASEAN have ratified the international human rights treaties.

The Implementation of the Prohibition of Torture, of course, will be the most difficult duty of the AICHR. As observed above, only three member states ratified the CAT, which means the other seven countries do not have any international obligation to prohibit torture in their jurisdictions. Another instrument which prohibits torture is ICCPR (article 3). At ASEAN level, ICCPR is only ratified by five member states (Cambodia, Indonesia, The Philippines, Thailand and Vietnam). As a matter of treaty law, a treaty does not constitute obligations to countries which do not ratify it. However, the prohibition of torture is considered to be a rule of "jus cogens" or peremptory norm as well as customary law (International Criminal Tribunal for the Former Yugoslavia-ICTY; Furundzija; 10 December 1998: paragraph 144-147). The prohibition of torture is absolute and non-derogable (ICTY; Furundzija: 10 December 1998, paragraph 144 and Manfred Nowak; 2006). These categorizations entail some obligations for states whether or not they ratify the CAT and the ICCPR, for example not to commit acts of torture in any case. Therefore, member states have the universal obligations to prevent torture and inhuman degrading treatment in their jurisdiction and there is no reason not to comply with the obligations under international customary law.

On the other hand, states which have ratified ICCPR have positive obligations to prevent torture within their jurisdiction. The obligations are stipulated in:

a) General Comment 1 of the CAT, paragraph. 6; "......are obliged to assess whether there are substantial grounds for believing that the author would be in danger of being subjected to torture were he/she to be expelled, returned or extradited, the risk of torture must be assessed on grounds that go beyond mere theory or suspicion....." b) General Comment 20 of the ICCPR, paragraph 14; States have duties to pass and enforce legislation, duties to investigate allegation of article 7, including duty to punish offenders (no amnesty for offenders) and positive obligation to prevent torture. These obligations enforced by article 7 should be read in conjunction with article 2 paragraph 3 of the ICCPR.

There is another declaration which bounds all states in the world; i.e. Universal Declaration of Human Rights (UDHR; 1948). Article 5 UDHR stipulates that "No one shall be subjected to torture or to cruel, inhuman or degrading treatment or punishment." Although UDHR is categorized as a soft law, at least this instrument can be used to implement the prohibition of torture for the countries which have not ratified the ICCPR and the CAT. The UDHR is considered to be the International Bill of Human Rights instead of the ICCPR and its two Additional Protocols and the ICESCR (International covenant on Economic and Social Rights). It has been served as the ethical and legal basis for all the human rights work of the United Nations (OHCHR; 1996). A Declaration, by definition is not legally binding instrument, but it has s strong moral force. (Rhona K.M. Smith; 2006: 39) The UDHR has been accepted widely that the norms stipulated in the UDHR form a part of the general principles of law. Judge Ammoun in his separate opinion on the Namibia Case (International Court of Justice-ICJ;1971), stated that: "the provisions of the Universal Declaration of Human Rights can bind States on the basis of custom......... whether because they constituted a codification of customary law...or because they acquired the force of custom through a general practice accepted as law". Needless to say, no state can avoid the UDHR's norms.

As a matter of fact, there are so many cases which constitute torture in ASEAN member states. For example in Myanmar, 
torture and other forms of ill treatment have been used to extract fictitious confessions that will be presented as evidence against the detainees. Detainees often do not receive immediate medical treatment, access to lawyers, family, and the courts. (Amnesty International, 2010) Furthermore, the New Constitution of Myanmar 2008 ensured impunity for the past violations of human rights. (Constitution of the Republic Union of Myanmar, 2008: Amnesty International: 2008 and 2009) The Constitution grants the army power to suspend all fundamental rights during an emergency and there are no provisions of freedom from torture and other ill-treatment. (Constitution of the Republic Union of Myanmar, 2008, chapter VII)

Torture and inhuman degrading treatment in ASEAN countries are not only happened in Myanmar but also in Cambodia (Human Rights Watch; 2010), Malaysia, Thailand, Indonesia. Malaysia has been critized because of its Internal Security Act (ISA) which allow for indefinite detention without trial and extended periods of incommunicado detention (detention without access to the outside world), have facilitated human rights violations, including torture and ill-treatment, and contributed to the climate of police impunity. (http://www.amnestyusa.org/) Article 73 (1) of Act 82 International Security Act, The Commissioner of Law Revision, Malaysia under The Authority of the Revision of Laws Act1968 in collaboration with Percetakan National Malaysia BHD, 2006, states that:

"Police may detain any person for up to 60 days, without warrant or trial and without access to legal counsel, on suspicion that "he has acted or is about to act or is likely to act in any manner prejudicial to the security of Malaysia or any part thereof or to maintenance of essential services therein or to the economic life thereof."

After 60 days, the Minister of Home Affairs can then extend the period of detention without trial for up to two years, without submitting any evidence for review by the courts, by issuing a detention order, which is renewable indefinite"

A systematic torture was happened in Southern Province of Thailand during March 2007 and May 2008. (Amnesty International; 2009) The Royal Thai Government has a right and a duty to protect its citizens from such abuses. The Government has stationed around 45 per cent of its military forces in the South has led to widespread human rights violations and has alienated the local population in the four predominantly Muslim southern Thai provinces affected by the insurgency: Narathiwat, Pattani, Yala and Songkhla. Thai security forces have systematically relied on torture and other cruel, inhuman or degrading treatment or punishment in their efforts to obtain information, to extract confessions to compensate for poor intelligence and evidence-gathering, and to intimidate detainees and their communities into withholding or withdrawing support for the insurgents. (Amnesty International; 2009)

Move on to the torture cases in Indonesia. On the mission to Indonesia, the Special Rapporteur on torture and other cruel, inhuman or degrading treatment or punishment found allegations and evidence of several cases of beatings by guards, often in relation to attempts to escape and violations of prison rules. (Human Rights Council, No. A/HRC/7/3/Add.4, 2008) The Special Rapporteur also founds a considerable number of allegations of torture and ill-treatment perpetrated by the police, either during arrest or in custody. The types of abuse include beatings with fists, rattan or wooden sticks, chains, cables, iron bars and hammers, kicking with heavy boots, electrocution and shots into the legs. Some detainees alleged that heavy implements (chairs, desks, and car jacks) had been placed on their legs for a prolonged period of time. The injuries sustained in a vast number of cases remain without any treatment, putting the health of the detainee further at risk. (Human Rights Council, No. A/HRC/7/3/Add.4, 2008)

With so many tortures and inhuman degrading treatments cases in its member states are posed challenges for the AICHR to 
overcome them. Since many of ASEAN countries do not ratified both $\mathrm{CAT}$ and ICCPR, the AICHR have to implement the prohibition of torture based on the customary international law. On the other hand, the AICHR has to urge the government of the member states to ratify the human rights instrument regarding torture in order to promote and protect human rights for ASEAN people. One thing that can also be done by AICHR is to monitor the national law regarding the prohibition of torture. The national law can be used to criminalize the perpetrator of torture in any case. The implementation of international norms on national level is the most important means for the individual impact. (David Weissbrodt and Joan Fitzpatrick; 2001:26) The writer agrees that choosing national mechanism is the best way to punish the perpetrator rather than choosing the regional mechanism, in this regard through the AICHR which is not yet well established.

The AICHR does not have an investigating function, which might help the victims to find the justice. It makes the AICHR lack of protection mandate and might not functioning well especially when dealing with the allegation of the prohibition of torture or other human rights' allegations within ASEAN jurisdiction. The AICHR TOR provides no guidance on how the AICHR must address either individual complaints or the governments which violate the fundamental rights of its nationals. (ACHR; 2009)

\section{National Legislation on the Prohibition of Torture in Indonesia}

Indonesia is one of member states of ASEAN which has ratified CAT and ICCPR,

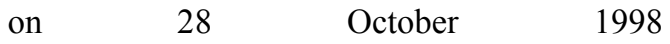
(http://treaties.un.org/Pages/UNTSOnline.aspx ?id=2) and 23 February 2006 (http://treaties.un.org/Pages/UNTSOnline.aspx ? $\mathrm{id}=1)$ respectively. Therefore Indonesia is bound by all the obligations stipulated in these conventions. In spite of these international norms, Indonesian constitution, as amended in 2002, guarantees a broad set of economic, social and cultural as well as civil and political rights. It recognizes the right for each person to be free from torture or inhuman and degrading treatment. (The 1945 Constitution of the Republic of Indonesia, Article 28 (G) 2) As for the national legislation regarding torture, Indonesia has the Criminal Code which stipulates maltreatment/mistreatment in Chapter XX, articles 351-358.

This crime is categorized as an ordinary crime, but the punishment might be increased by one third if it is carried out by a public official. (The Indonesian Criminal Code, Article 356 (2)) This provision has the possibility to criminalize the officials for torturing the suspect, although the provision lacks several elements of the torture definition under article $1 \mathrm{CAT}$, such as the elements of purpose, mental pain or suffering, and agency (i.e. inflicted or instigated by a public official or with his or her consent or acquiescence). (Human Rights Council, No. $\mathrm{A} / \mathrm{HRC} / 7 / 3 /$ Add.4; 2008:10) Indeed the Criminal Code provides the punishment for the perpetrator but it does not provide sufficient legal deterrent to prevent official from committing torture, which has directly contributed to the widespread use of torture during arrest, interrogation and detention. (Amnesty International; 2008) Needless to say, the Criminal Code has a limited effectiveness. This fact is likely to be a problem in preventing and abolishing the act of torture in Indonesia. The use of torture to get the confession is widely used by the police, while not all the perpetrators are brought to the Court of Law and are given an equitable sentence.

Besides the Criminal Code, Indonesia has the Laws on Human Rights 39/1999 and Human Rights Courts 26/2000. The Prohibition of torture is stipulated under Article 1(4), 4, 33, 34 and 66 of the Laws on Human Rights 39/1999. The definition of torture stipulated in article 1(4) includes:

"Torture means all deliberate acts that cause deep pain and suffering, both physical or emotional, inflicted on an individual person to obtain information or knowledge from that person or from a third party, by punishing an individual for an act 
carried out or suspected to have been carried out by an individual or third party, or by threatening or coercing an individual or third party, or for reasons based on discriminative considerations, should this pain or suffering arise as a result of provocation by, with the approval of, or with the knowledge of any person or public official whosoever."

The Indonesian definition has been included the aspect of torture in the CAT definition, which are: severe pain or suffering either physical or mental, intention purposes and done by public official. This Law also states that right not to be subjected by torture is categorized as non-derogable right (Article 4). Furthermore, in article 9 of the law 26/2000 concerning Human Rights Court states that torture is categorized as a crime against humanity if perpetrated as a part of a broad or systematic direct attack on civilians. Article 75 and 76 of The Law 39/1999 establish the National Committee of Human Rights (KOMNAS HAM) which has the authority to receive complaints and conduct preliminary inquiries "pro justicia investigation" into allegations of gross human rights violations and to hand them over to the Attorney-General's office for further action.

Although Indonesia has a comprehensive law which prohibits torture or inhuman and degrading treatment, many torture-related cases still happened as mentioned previously. This happened because of the poor implementation from law enforcement officials. The police as an investigation body still use torture to extract confession or information. (Human Rights Council, No. A/HRC/7/3/Add.4, 2008). They do not realize that actually their action is prohibited by the law. Giving Education to police officers as stipulated in Article 10 of the CAT is needed here. Also, educating the suspects is very important in order to make them realize their rights, which enables them to refuse or report the abuse perpetrated to them. The Special Rapporteur noted that there is no functioning monitoring mechanism in Indonesia. (Human Rights Council, No.
A/HRC/7/3/Add.4, 2008) Indeed, some NGOs have access to detention and prison but there is no independent and effective mechanism which would have the power to conduct unannounced visits to all places of detention throughout the country. (Human Rights Council, No. A/HRC/7/3/Add.4, 2008).

As stated above, Indonesia has the National Commission on Human Rights (KOMNAS HAM) which function to do research, to study, to disseminate, to monitor and to mediate human rights issues (article 76 Law 39/1999). The function which related to the acts of torture is monitoring or supervisory function. Article 89 (3) Law 39/1999) stipulates that the monitoring function include:

a. monitor the implementation of human rights and compile reports of the output of this monitoring;

b. investigate and examine incidents occurring in society which either by their nature or scope likely constitute violations of human rights;

c. call on complainants, victims and accused to request and hear their statements;

d. call on witnesses to request and hear their witness statements, and in the case of prosecution witness to request submission of necessary evidence;

e. survey incident locations and other locations as deemed necessary;

f. call on related parties to give written statements or to submit necessary authenticated documents as required upon approval of the Head of Court;

g. examine houses, yards, buildings, and other places that certain parties reside in or own, upon approval of the Head of Court; 
h. on approval of the Head of Court, provide input into particular cases currently undergoing judicial process if the case involves violation of human rights of public issue and court investigation, and the input of the National Commission on Human Rights shall be made known to the parties by the judge;

If we paid attention on the monitoring function above, it looks that KOMNAS HAM's function might be very complex, because it has a powerful function. Not only monitor implementation ad compiling report, but also receive individual complaint. Article 89 (3) part b states that KOMNAS HAM may investigate and examine incidents which more likely constitute violations of human rights. However, article 18 of the Law 20/1999 concerning The Human Rights Court limits the investigation function of the KOMNAS HAM only on grave breaches violation of human rights. This law stipulates that grave breaches of human rights are including genocide and crime against humanity (article 7). While torturing individual would not fall under the category of grave breaches, because it does not fulfil the wide spread and systemic attack; therefore, KOMNAS HAM would not investigate it more over bring the case to the human rights court, which only has competence to hear the cases on grave breaches violation of human rights (article 4). Needless to say, torture will never be heard before the human rights court in Indonesia unless it fulfils the two requirements above.

There is one possibility to claim the violation of human rights for the torture victims before the KOMNAS HAM by employing its mediation function (Law 39/1999 Article 89 (4)). However, there is one weakness of this function which is the result. The mediation primarily uses consultation, negotiation and conciliation. All these three means are used for the pacific dispute settlement. Through mediation, a case either might be or might not be solved. If the case is not solved then KOMNAS HAM will make a recommendation to the parties to bring their case before the court. However, the recommendation is not binding, it means that the parties might or might not use it. In this regard, the writer does not agree if the acts of torture were solved by peaceful settlement. Torture is a criminal act. Mediation will never erase the pain of the victims. Therefore, the perpetrator must be brought before the court to be responsible for his actions. This method will also serve as a prevention action, in order to give lesson learned to the society for not committing the acts of torture.

As observed above KOMNAS HAM with its function based on the Law 39/1999 was unable to stop or prevent the acts of torture. Therefore, there are two possibilities to overcome this problem which are either to revise the law 39/1999 on the KOMNAS HAM's mandate or to ratify the Optional Protocol to the Convention against Torture and Other Cruel, Inhuman or Degrading Treatment or Punishment (OPCAT 2002) by the Indonesian Government might be the best choice. This instrument requires the establishment of a National Preventive Mechanism (NPM) which has mandate to conduct independent monitoring based on unannounced visits to all places where persons are deprived of their liberty.(OPCAT; 2002: article 1)

\section{Conclusion}

Torture or inhuman and degrading treatments are still happening in ASEAN countries. The problems at the ASEAN level are: first, lack of ratification of international human rights conventions within the member states. Second, the new human rights body is still trying to figure out its duty. Third, there is no regional human rights declaration. Scholars feel cynical about this body, because ASEAN has some of the world's most notorious human rights violators, in particular Myanmar (Yuval Ginbar; 2010) and now all member states try to work based on consensus. Therefore the duty to protect human rights is very challenging, primarily in establishing the ASEAN Declaration of Human Rights which 
bind all the member states in order to protect human rights for all people in ASEAN.

As for Indonesia, the challenge is the law enforcement for all the law in effect, also to ratify the Optional Protocol to the Convention against Torture and Other Cruel, Inhuman or Degrading Treatment or Punishment (2002) in order to provide monitoring mechanism to prevent torture or inhuman and degrading treatment. Indonesia as one of the member states of ASEAN together with all the member states has to support the ASEAN system to be much better than today. Finally, the ASEAN human rights system will be well established as it is in another region such as European, InterAmerican, and also the African system. 


\section{BIBLIOGRAPHY}

\section{Primary Sources:}

The Universal declaration of Human Rights, 10 December 1948, http://www.un.org/en/documents/udhr/, date of access 12 October 2010

International Covenant on Civil and Political Rights, New York, 16 December 1966, United Nations, Treaty Series, vol. 999, p. 171 and vol. 1057, p. 407

International Court of Justice, Namibia Case (Legal Consequences for States of the Continued presence of South Africa in Namibia (South West Africa) Notwithstanding Security Council Resolution 276 (1970), Advisory Opinion, 1971, ICJ Reports 16.

International Criminal Tribunal for Former Yugoslavia, Prosecutor v. Anto Furundzija, 10 December 1998, Case No.: IT-95-17/1-T

Convention against Torture and Other Cruel, Inhuman or Degrading Treatment or Punishment, New York, 10 December 1984, United Nations, Treaty Series, vol. 1465, p. 85.

Optional Protocol to the Convention against Torture and Other Cruel, Inhuman or Degrading Treatment or Punishment, New York, 18 December 2002 , United Nations, Treaty Series, vol. 2375, p. 237;

Charter of Association of South East Asian Nations, Singapore, 20 November 2007, http://www.ASEANsec.org/publications/ASEAN-Charter.pdf, date of access 12 October 2010

ASEAN Secretariat, Term of References of ASEAN Intergovernmental Commission for Human Rights, Jakarta, 2009, http://www.ASEANsec.org/publications/TOR-of-AICHR pdf, date of access 12 October 2010

Constitution of the Republic Union of Myanmar 2008, Ministry of Information, 2009, http://www.burmalibrary.org/docs5/Myanmar_Constitution-2008-en.pdf, date of access 13 October 2010

International Security Act, The Commissioner of Law Revision, Malaysia under The Authority of the Revision of Laws Act 1968 in collaboration with Percetakan National Malaysia BHD, 2006, http://www.mylawyer.com.my/pdf/Internal_Security_Act.pdf, date of access 13 October 2010.

General Assembly, Human Rights Council, No. A/HRC/7/3/Add.4, Report of the Special Rapporteur on torture and other cruel, inhuman or degrading treatment or punishment, Manfred Nowak, Mission to Indonesia, 10 March 2008, http://daccess-ddsny.un.org/doc/UNDOC/GEN/G08/114/90/PDF/G0811490.pdf., date of access 13 October 2010.

The 1945 Constitution of the Republic of Indonesia, As amended by the First Amendment of 1999, the Second Amendment of 2000, the Third Amendment of 2001 and the Fourth Amendment of 2002, http://www.embassyofindonesia.org/about/pdf/IndonesianConstitution.pdf, date of access 14 October 2010. 
Annual Report of the National Human Rights Commission of Indonesia 2006, http://www.komnasham.go.id/portal/en/content/, date of access 13 October 2010.

Kitab Undang-Undang Hukum Pidana Indonesia (Indonesian Criminal Code) taken from Soenarto Soerodibroto, Fourth edition, Raja Grafindo Persada, 2002

Legislation Number 39 of 1999 concerning Human Rights, http://www.komnasham.go.id/portal/files/, date of access 11 October 2010

Legislation Number 26 of 2000 Concerning Human Rights Courts, unofficial translation, http://www.komnasham.go.id/portal/files/, date of access 11 October 2010

General Comment No. 01 of the Conventions Against Torture, the Implementation of article 3 of the Convention in the context of article $22:$. 11/21/1997. A/53/44, annex IX.

General Comment No. 20 of the International Covenant on Civil and Political Rights, Replaces general comment 7 concerning prohibition of torture and cruel treatment or punishment (Art. 7) : . 03/10/1992.

\section{Secondary Sources}

\section{Books:}

David Weissbrodt and Joan Fitzpatrick, International Human Rights: Law, Policy, and Process, Third edition, Anderson Publishing Co., Ohio, 2001.

Office of the High Commissioner for Human Rights (OHCHR), the International Bill of Rights Fact Sheet 2, Rev. 1, Geneva, 1996.

Rhona K.M. Smith, Textbook on International Human Rights, $2^{\text {nd }}$ Edition, Oxford University Press, Oxford, 2005

\section{Periodical Journals}

Manfred Nowak, What Practices Constitute Torture?: US and UN Standards, Human Rights Quarterly, Volume 28, Number 4, November 2006, pp. 809-841

Maznah Mohammad, Towards a Human Rights Regime in Southeast Asia: Charting the Course of State Commitment, Contemporary Southeast Asia (24) 2, 2002

Yuval Ginbar, Human Rights in ASEAN-Setting Sail or Treading Water?, Human Rights Law Review (10) $3,2010$.

\section{NGO reports}

Amnesty International, Myanmar Elections -- Amnesty International Reacts, 13 August 2010, Myanmar, http://www.amnestyusa.org/all-countries/myanmar-burma/, date of access 13 October 2010.

Amnesty International USA, Thailand: Torture in the southern counter-insurgency, EMBARGOED FOR 0400 GMT 13 January 2009, http://www.amnestyusa.org/, date of access 13 October 2010. 
Amnesty International, Report 2009, Human Rights in Union of Myanmar, 2009, http://www.amnesty.org/en/region/myanmar/report-2009, date of access 13 October 2010

Amnesty International, Report 2008 regarding torture and ill-inhuman treatment in Myanmar, http://www.amnesty.org/en/region/myanmar/report-2009, date of access 13 October 2010

Human Rights Watch, Cambodia: Sex Workers Face Unlawful Arrests and Detention, Officials Should Investigate and Close Government Centers Where Abuses Occur, 20 July 2010, http://www.hrw.org/, 13 October 2010

\section{Others}

Amnesty International, Public Statement: Indonesia: Investigate ill-treatment of Papuan prisoner, AI Index No: ASA 21/019/2008, 25 September 2008

Asian Centre for Human Rights, Weekly Review, ASEAN's new human rights body: A threat to human rights in the region?, Review/226/2009, Website: www.achrweb.org

Mr. Termsak Chalermpalanupap, 10 Facts about ASEAN Human Rights Cooperation, available at http://www.asean.org/HLP-OtherDoc-1.pdf, date of access 30 October 2010 